\title{
LIVING AT THE MARGINS: WOMEN AND NATIONAL IDENTITY IN PAINS
} OF AUTUMN

\section{Emine Yeşim BEDLEK*}

\begin{abstract}
One of the most catastrophic events in modern Turkish history occurred on September 6-7, 1955. Fuelled by Turkish nationalism, riots targeting non-Muslim minorities aimed to homogenize the demographics and economy of the Turkish Republic. Political and social problems between Turkey and Greece had been threatening the lives of minorities for some time. In 1955, with the Cyprus issue accelerating tensions between Greece and Turkey, thousands of homes and shops were plundered in Istanbul, Izmir, and Ankara, with Greeks, Jews, and Armenians suffering material and spiritual harm. This sensitive issue is presented in Y1lmaz Karakoyunlu's Pains of Autumn [Güz Sanc1s1], a novel in which the author portrays the lives of Muslim Turks and non-Muslim minorities of Turkey during the September 1955 events. This article analyzes the role of women as symbols (and makers) of nations, specifically in Pains of Autumn. It becomes evident that Karakoyunlu reveals his nationalist mindset in his treatment of the female characters and illustrates the close relationship between gender and nationalism in the book.
\end{abstract}

Keywords: Pains of Autumn, 6/7 September Events, Greece, Turkey, gender, nationalism.

\section{SINIRLARDA YAŞAMAK: GÜZ SANCISI'NDA KADIN VE MİLLİ KİMLİK}

\section{$\ddot{O} z$}

Yakın dönem Türkiye tarihinin önemli siyasi ve toplumsal hadiselerinden biri olan 6/7 Eylül Olayları, 1950'li yıllar Türkiye'sinin uygulamayı düşündüğü azınlık politikalarının ve çeşitli milliyetçi grupların tek tipleştirme politikasının bir sonucu olarak yaşanmış en elim hadiselerinden birisidir. Özellikle Türkiye ile Yunanistan arasında devam eden Kıbrıs Sorunu gerginliğinin tırmandırdığı milliyetçi duygular, Atina'daki Atatürk'e ait müze evinin kundaklandığına dair çeşitli söylenti ve haberler; İstanbul, İzmir, Ankara'da yaşayan gayrimüslimlere yönelik bir linç kampanyasına dönüşmüş, bu gruplara ait, ibadethaneler, evler ve işyerleri talan edilmiştir. 6/7 Eylül Olayları nedeniyle Türkiye'de yaşayan azınlıklar, hem maddi hem de manevi bir yıkım yaşamış, bu olaylardan sonra gayrimüslim nüfusun önemli bir kısmı ülkeyi terk etmek zorunda kalmıştır. Türk edebiyatında önemli tarihi olayları romana taşıyan ve tarihi

\footnotetext{
Makale Gönderim Tarihi: 13.09.2018, Kabul Tarihi: 26.12.2018

Doi: $10.26791 /$ sarkiat.459824

* Dr. Öğretim Üyesi, Bingöl Üniversitesi İngiliz Dili ve Edebiyatı Bölümü. eybedlek@bingol.edu.tr ORCID ID: 0000-0001-7624-7016
} 
romanda yaşatmaya çalışan son dönemin önemli yazarlarından olan Yılmaz Karakoyunlu, 6/7 Eylül Olaylarını ve Türklerin ve gayri-Müslim azınlıkların birbirleriyle olan ilişkilerini Güz Sancısı adlı romanında ele almış, böylece bu önemli hadiseye bir edebiyatçı olarak tanıklık etmek istemiştir. Bu makale Güz Sancısı adlı romanda kadının milli kimlik inşasındaki rolünü incelemektedir. Romandan anlaşıldığ üzere Karakoyunlu kadın karakterler üzerinden milliyetçi bakış açısını gözler önüne sermektedir ve kitabında toplumsal cinsiyet ile milliyetçilik arasındaki yakın ilişkiyi ortaya koyduğu aşikârdır.

Anahtar Kelimeler: Güz Sancısl, 6/7 Eylül Olayları, Türkiye, Yunanistan, toplumsal cinsiyet, milliyetçilik.

\section{INTRODUCTION}

The aim of this article is to analyze the role of women as symbols (and makers) of nations in Y1lmaz Karakoyunlu's Pains of Autumn, a novel that in part attempts to draw the attention of Turkish people to episodes of violence in the history of modern Turkey. The author not only describes the horrors of the September 1955 events but also the horrific and deeply-rooted Turkish nationalism that fuelled the riots. A feminist reading of the novel, however, reveals the author's own nationalist sentiment in the way he depicts the primary women characters, Rhea and Ester. While Karakoyunlu tries to draw our attention to contemporary issues facing the Turkish Republic and dives into sensitive issues concerning Turkish history and politics generally disregarded by the Turkish people, he cannot overcome his nationalist sentiments toward its non-Muslim citizens. Non-Muslims in Pains of Autumn are humiliated through women characters that are depicted as being morally corrupt. The sexual abuse they endure represents a double humiliation: national origin and gender. Women are demonized by nationalist authors like Karakoyunlu in order to differentiate their nation from the "Other." For the Turkish Republic, the "Other" represents the national enemy and former minority subjects within the Ottoman Empire. Minorities, as legacies of the Ottoman era, had to be either assimilated or eliminated. This ideology is reflected in the works of writers like Y1lmaz Karakoyunlu. Before analyzing the relationship between gender and nationalism in Pains of Autumn, the social and historical context of the novel will be outlined.

Pains of Autumn, published in 1991, is Karakoyunlu's second historical novel. It gives voice to the sufferings of the victims of the September 1955 events. The novel takes place in Istanbul, specifically in the Beyoğlu, Galata, Şişhane, Beyazıt, and Taksim neighborhoods that were mostly populated by non-Muslim Turkish citizens during the Prime Ministry of Adnan Menderes and his liberty- and welfare-promising Democrat Party (Akgönül 2007:163). Pains of Autumn portrays these events, also known as the "Istanbul Pogrom" or the "Istanbul Riots," which targeted non-Muslim minorities, including the Greek-Orthodox community of Istanbul (otherwise known as the Rum or Constantinopolitan Greeks ${ }^{1}$ ), Jews, and Armenians. The September Events reflected the goals of the Turkish state at the time: nationalization of both the population and the economy. The Turkish Republic, founded on the ashes of the Ottoman Empire in 1923, was composed of diverse ethnic groups and religions. The minorities of the early

\footnotetext{
${ }^{1}$ These terminologies refer to the Orthodox Christians of Istanbul who were the old residents of the Byzantine Empire. I will use these terminologies interchangeably in this article.
} 
Turkish Republic were not regarded as Turks even though they spoke Turkish and continue to do so today. According to Soner Çağaptay, they were "imperfect citizens" of the Republic (2006:1). Only Turks were regarded as full members of the nation; the minorities were not regarded as such.

With the foundation of the Republic, the Ottoman legacy was buried, and the unification and Turkification policy of the state commenced. Populations were homogenized with the Lausanne Convention signed by Greece and Turkey in 1923 (Ar1 2010:1). By political agreement, the Orthodox Christian populations of Asia Minor and the Muslim populations living in Greece were exchanged (deported) across the Aegean Sea against their respective wills. With the forced migration of millions of people from their homeland, Greece and Turkey homogenized their demographics and, in doing so, tore families, cultures, and traditions apart (Hirschon 1998). The "Wealth Tax" can be regarded as another way of Turkification issued by the Turkish Republic during the Second World War. In his memoirs, Faik Ökte narrated that he prepared a list of taxpayers and devided those taxpayers into two categories: Muslims and non-Muslims. However, the tax issued to non-Muslims was higher and Orthodox Christians of Istanbul suffered more than the other non-Muslim citizens of Turkey (Akgönül 2007:120). Events leading up to September 1955 not only targeted the minorities financially, but also their well-being - as they were harmed both psychologically and physically. An insecure atmosphere was stirring, and the minorities felt threatened with the rise of Turkish nationalism and its episodic violence.

Dilek Güven's book, Cumhuriyet Dönemi Azınlık Politikalarl ve Stratejileri Bağlamında 6-7 Eylül 1955 Olaylarl [The September 6-7 Events in the Context of Minority Strategies and Policies in the Republican Era] includes both archives and oral witness accounts which describe the tragic events from various perspectives. Although many researchers have consulted these oral histories, doubts remain concerning their reliability (Grele 1998:38). Güven, however, believes that oral history shares practically the same features as official history in that they both can be affected by ideology (2014: 21-22). For Paul Thompson, oral history represents a democratic forum, as it voices the sufferings of victims (2000:9). The main resource of oral history is the memory of those who were eyewitnesses to the grand events of history. History and memory are closely linked because historical knowledge depends on memory. As David Lowenthal claims, "All past awareness depends on memory. Recollection recovers consciousness of former events, distinguishes yesterday from today, and confirms that we have a past" (2015:303). Some historians consult memory for a better understanding of the past.

Güven is aware of the capacity of oral history to shed light on past events. She successfully combines both oral and official history to give voice to the silenced past of the non-Muslim minorities of Turkey. According to Güven, the pogrom sought to nationalize the economy, to diminish the economic power of non-Muslims, and to transfer social, economic, and institutional power to Muslim Turks (2014:13). Adnan Menderes, the Prime Minister of Turkey between 1950 and 1960, himself promised a liberal economy and democratic society that pleased non-Muslims. However, the Islamic background of his party, the DP, favored Muslims over non-Muslims in many sectors of society, including finance and education. In addition, since the country's economy was not doing well during the second half of the 1950s, Menderes and his cabinet wanted to divert attention away from the economy and onto the Cyprus issue (Güven 2014:14). After the Second World War, the Orthodox Christians of Cyprus wanted to unite with Greece in a process of reunification the Greeks call enosis. The two motherlands were actively involved whenever an issue was raised in Cyprus. 
According to Alexis Heraclides, "Their active involvement was prompted by the Greek Cypriot call for enosis [...] followed by the Turkish Cypriot's taksim (partition)" (2010:70). Menderes placed this sensitive issue at the center of his domestic politics, and evidence indicates that the Istanbul Pogrom of 1955 was initiated by DP leaders and their supporters (Güven 2014:14). As Ahmet İçduygu states, "Non-Muslim minorities from time to time suffered socio-political and economic consequences within the country whenever Turkish governments faced diplomatic crises abroad" (2008:371). The nationalist policies of Greece and Turkey created problems and conflicts in Cyprus that whipped up social tension leading toward September 1955.

On September 6, 1955, the Istanbul Express newspaper announced that Greeks had bombed the birthplace of Mustafa Kemal Atatürk in Thessalonica. The news aroused the nationalist feelings of Turks, for whom the country's founder was and remains a sacred figure. However, the real story was different. The event was initiated by a bomb thrown by Oktay Engin, a Rumelian Muslim living in Thessalonica. He was a law student whose expenses were being paid for by the Turkish state (Güven 2014:92). He had also been promised a government position in Turkey. In 1956 that promise became a reality when he returned to Turkey and became a governor in the province of Nevşehir (Güven 2014:93). Nevertheless, Greeks were blamed instead and a meeting to protest the bombing was organized by student associations and the "Cyprus Is Turkish Association" in Istanbul's Taksim Square. After the meeting, some people started to stone and loot shops owned by non-Muslims in Beyoğlu, Taksim, Nışantaşı, Şişli, Eminönü, Fatih, Yeşilköy, Bakırköy, Ortaköy, Eyüp, Arnavutköy, Bebek, Kuzguncuk, Çengelköy, Moda, Kadıköy, and also the Princes' Islands off the coast of Istanbul in the Marmara Sea (Güven 2014:25). In addition to the shops, the Turkish mob destroyed houses, churches, and Jewish, Greek, and Armenian cemeteries. The mobs "were given axes, crowbars, acetylene torches, petrol, dynamite, and large numbers of rocks in carts" (Zayas 2007:340). Preparations for the assault had apparently started several days earlier. Speros Vryonis explains how the "Cyprus Is Turkish Association" conceived and organized the riot:

The new organization's first job was to prepare a brochure explaining why Cyprus was Turkish and justifying Turkish claims on the island on historical, geographical, strategic, and other grounds. After producing and circulating the Turkish version, English, French, Spanish, Italian, German, and Arabic editions were produced and sent throughout the world. At the same time, the committee began feverishly to organize and provide material assistance to chapters throughout Istanbul and all of Turkey (2005:50).

Şerif Demir claims that people were brought by train from Eskişehir and by trucks from areas near Istanbul (2007:44). The groups were 20-30 strong, and classified as provocateurs, leaders, and looters (Güven 2014:26). Furthermore, "the mobilization of the perpetrators and their equipment inside the city was guaranteed by a transportation network composed of private cars, commercial taxis and trucks, ferries and even military vehicles. The rioters thus easily determined their targets and accomplished their attacks successfully throughout the city" (Güven 2011:4). Property belonging to nonMuslim minorities was identified before the riot, and group leaders checked lists of properties that belonged to minorities while others destroyed shops and houses (Güven 2014:27). The police simply stood by during the riot and encouraged people to continue plundering (Güven 2014:27; Bali, 2014: 71-79-332). When people asked the police the reason for their passive attitude, they told them that they were not allowed to intervene 
on orders of the government. Moreover, firefighters delayed in extinguishing the fires that burned the houses and churches (Güven 2014:36). Riots not only took place in Istanbul, but in Izmir and Ankara, as well (Güven 2014:39-43). Hundreds of people were injured, and some Greek women were raped (Güven 2014:54). Thousands of shops and houses were damaged, as well as churches and schools in the ownership of non-Muslims.

Rifat Bali collected memoirs from eyewitnesses of the September Events in 6-7 Eylül 1955 Olaylarl: Taniklar-Hatıralar [September 6-7 1955 Events: Witnesses-Memoirs]. According to eyewitnesses, the riot was organized by the state against non-Muslims. Moreover, Muslim Turks were aware of the riot as they warned their non-Muslim neighbors and friends to close their shops and go home immediately. Many of them were saved in this way (Bali, 2014: 45-85-89). During the riot, some people even attacked the cemeteries and ripped Christian corpses from their graves (Bali, 2014: 4890-98). Apart from the plundering in the city center, the Princes' Islands off IstanbulBüyükada and Heybeliada - were plundered by mobs that were ferried to the islands from the Kartal district. They destroyed and plundered shops to the point that residents of the islands faced famine in the ensuing weeks (Bali 2014:56). Eyewitnesses stated that the mobs were actually construction workers from Istanbul who were given the necessary tools to destroy the property of the minorities (Bali 2014:376). Aydin Boysan, a well-known Turkish architect, was working at a construction site in the Haliç/Sütlüce district during those days. On September 7, he went to the construction site as usual, and saw the workers resting instead of working because they were all exhausted owing to their looting the previous night. Boysan ordered the workers to return everything they stole. The workers refused, however, and instead hid everything in a big hole (Bali 2014:18-19).

Bali's book contains two oral testimonies in the plunderers' own words. One of them comes from Mikdat Remzi, a worker who was in a café in Tophane with one of his friends when he heard the news of the bombing of Atatürk's birthplace. Meanwhile, the police were giving orders to destroy property belonging to non-Muslims. Remzi joined the plunderers and attacked a jewelry shop. He was aware of what he was doing and felt guilty for stealing (Bali 2014:355-356). The other plunderer, İsmail Kazdal, first resisted the perpetrators since some of his friends were members of the Greek minority. However, his nationalist feelings were aroused and he decided to attack the houses of Greeks he did not like. Kazdal reveals in the memoir the realization that people can be easily manipulated into mob-type behavior and can cause harm at any time (Bali 2014:364-365). Mihalis Vasiliadis's narrative of the experiences of the September Events also appears in Bali's book. He lived in a building with several non-Muslim residents in Beyoğlu. When the riot started, the doorman of the building locked the main gate, held up a Turkish flag, and protected all the non-Muslim residents living in the building. The mobs did not destroy the building and left, thanks to the efforts of the doorman. He saved the lives of all those people, but joined the plunderers and later destroyed shops belonging to non-Muslims that he did not know personally (Güven 2014:38-39). Obviously, the doorman did not have any kind of prejudices towards the non-Muslims because he worked for them. He was in close contact with those Christians and Jews on daily basis. Psychologically, he was torn between two loyalties: the residents of the apartment and his nation. Perhaps he was facing the greatest contradiction in his life, one not easy to overcome. When he finished his first duty in the apartment, he turned to the streets to "serve" his nation. He tried to satisfy both parties at the same time. Furthermore, the bombing of Atatürk's birthplace is an extraordinary 
event to face and cope with as the children of the Republic were raised with the glorious victory of the Turks over the Greeks during the War of Independence (1919-1922) led by Atatürk, the father of Turks.

Another very interesting story is narrated by a Turkish intellectual, Aziz Nesin, who was one of the eyewitnesses of the September Events. He was dining in a restaurant with one of his friends in Beyoğlu. When the mobs entered the place-called the Izmir Restaurant - the owner, a non-Muslim, begged the mobs not to destroy the restaurant and claimed that he was not Greek, but actually a Muslim Turk. In order to prove his claim, he held up a photo of Atatürk and ordered his waiters to bring all the photos of Atatïrk from the basement of the restaurant. Nesin was shocked to see several framed photos of Atatürk in the restaurant (Bali 2014:166). This particular event shows that non-Muslims were aware of the violent Turkish nationalism that could attack them anytime and anywhere and thus took measures (even quite ordinary ones) to protect themselves against any nationalist attack. It is also worth noting the role of the Turkish flag in these events. Several non-Muslims saved their lives through hanging or holding onto Turkish flags (Bali 2014:81-92-349). As Michael Billig notes, national flags constantly remind citizens that they are part of a nation to which they must be loyal (1995:5). Mobs did not destroy the shops and the houses with Turkish flags on display. Some people made their own Turkish flags with red cloth they had at home. Albert Sevinç told the story of the red satin suit he was planning to wear to a wedding. When the mobs started to destroy the houses of the Greeks and Armenians in Kumkapı, his father panicked and cut his red suit into pieces and managed to make a Turkish flag to rescue his household. Sevinç never forgot that moment and never wore red for the rest of his life (Bali 2014:126). Garbis Özatay's house was also under attack, and his father made a Turkish flag out of his shirt and his wife's blouse in order to save their lives (Bali 2014:255). In sum, non-Muslims were aware of how to cope with Turkish nationalism.

Celal Bayar, the President of the Turkish Republic, and Adnan Menderes, the Prime Minister, were on their way to Ankara during the riots, but immediately returned to Istanbul upon being informed of the events. Martial law was declared in order to establish security in Istanbul, Ankara and Izmir. Nonetheless, the physical and verbal attacks aimed toward non-Muslims did not end until November (Güven 2014:44-45). Thousands of people were arrested, but only 228 were sentenced in 1956 . Thousands were released and, İsmet İnönü, the leader of the opposition party (and Atatürk's former vice-president, advisor, and fellow soldier during the war for liberation), criticized the government for releasing those people (Güven 2014:72). The state blamed the riots on Communists. On September 7, forty-eight Communist intellectuals were arrested, including Aziz Nesin, Kemal Tahir, Ratip Tahir, İsmet Selimoğlu, Emin Sekün, and Ziya Tüzmen, many of whom were already under investigation for supposed ideological crimes. The police carelessly prepared a list of suspects, including dead people as well as people who were serving in the military at the time (Güven 2014:74). Those people were kept in detention until the end of 1955 when they were finally, without any explanation, released (Güven 2014:75). Since the Istanbul Express was owned by Mithat Perin, who was a member of the DP, people believed that he was one of the initiators of the September Events. In an interview, Perin, however, rejected the accusations (Bali, 2014:305). He was arrested after the riots, but was released in two hours on the orders of Adnan Menderes (Bali, 2014:94). According to reports compiled by the German and British Embassies, the riot was organized by the Menderes government, but whoever the organizers were certainly could not have predicted such a 
scale of destruction and plunder (Bali, 2014:94-95).

Having faced the violence and extremism of Turkish nationalism, many of the country's non-Muslims felt threatened and left (Bali, 2014: 84-259-284-293). Those who remained always felt insecure, as Hrant Dink wrote in Agos newspaper just before his assassination by a Turkish nationalist in 2007. Dink, a Turkish-Armenian and editor-inchief of Agos, was accused of insulting Turkishness in his articles. Doing so is considered a criminal act under the Turkish constitution. During the trial, he was sure that his sincere attitude and writings would convince the members of the court that he did not mean to insult Turkishness at all. He was threatened by many Turkish nationalists, and described his feelings: "I am just like a dove. Like a dove's, my gaze flits right, left, forward, back. My head is just as fidgety, and quick to turn" (2007). Dink captured the feelings of all minorities in Turkey who felt uneasy owing to the policies of the Turkish state, even five decades later. Dink continues: "I know that in this country, nobody ever hurts doves. Doves live their lives in the hearts of cities, amid the crowds and human bustle. Yes they live a little uneasily, a little apprehensively-but they live freely too" (2007). Dink was hopeful that he would not be hurt by anyone in Turkey, but fell to an assassin's bullet on January 17, 2007.

\section{Woman and Nation}

Y1lmaz Karakoyunlu, a Turkish politician, novelist, playwright, and poet, has published several historical novels that deal with the history of modern Turkey: Çiçekli Mumlar Sokağı [Candles-with-Flowers Street], Salkım Hanımın Taneleri [Mrs. Salkım's Diamonds], Yorgun Mayıs Kisraklarl [Exhausted May Mares], and Perize: Ezan Vakti Beethoven [Perize: Beethoven During Call for Prayer]. As a political figure, he is engaged with "secular centre-right politics [and] was steeped in a political party atmosphere at a young age because of his father's engagement with the DP" (Günay 2015:§56). He became a member of the Turkish Parliament in 1995 as an MP (from the district of Istanbul) with the ANAP (Motherland Party) (Günay 2015:§57). His first novel, Mrs. Salkım's Diamonds (1990), criticizes the Wealth Tax imposed on nonMuslim minorities in 1942, and was subsequently filmed and broadcast by state television. Mrs. Salkım's Diamonds "caused friction in the coalition government, putting [the] ANAP and the MHP (Nationalist Action Party) in conflict and gave rise to a motion questioning the 'hidden agenda' of the novel and the film" (Günay 2015:§59). Karakoyunlu was thus accused of disloyalty owing to certain interpretations of the book and movie.

Both the Wealth Tax and the September Events occurred in his lifetime. He was actually an eyewitness to the September Events (a nineteen year old at the time), watching firsthand the destruction of many shops and a church in Taksim (Bali 2014:255). Owing in large part to his ideological background, he does not objectively criticize the minority policy of the Turkish Republic in Pains of Autumn, nor does he inform readers who the perpetrators of the riot actually were (Millas 2000:146). There may be two reasons for his silence on these issues: first, he is a right-wing politician, and the DP was a right-wing political party in 1950s. Second, after the publication of his first historical novel, Mrs. Salkım's Diamonds, he was accused of disloyalty. For nationstates, loyalty is one's foremost duty to one's nation. My argument here is that Karakoyunlu was working from a nationalist mindset in the writing of Pains of Autumn, and consequently the book follows the patterns of other nationalist literature. To demonstrate my thesis with regard to Karakoyunlu's novel, it is important to begin with a general discussion of nationalism - its history, politics, myths, and literature. 
Nationalism emerged as the most popular ideology of the twentieth century. It eliminates or assimilates different ethnic groups to form homogenized populations that share the same language, culture, religion, and history with some mythical past. Shlomo Sand claims that the agents of memory work hard to invent mythical pasts to augment and underpin a nation's handsome portrait (2009:15). According to Michalis N. Michael, nationalism and a myth-constructed past are inseparable. Nationalism reconstructs and appropriates the past in its own way, and survives partly through the spreading of myth (2010:249). Nationalist ideology seeks to dominate the state, promoting and exaggerating its culture, language, and history (Karpat 2010:37). Nationstates under such ideology produce closed societies and indoctrinate their citizens to hate the "Other," who is perceived as enemy of state and nation. Benedict Anderson defines "the nation" quite remarkably in his claim that it "is an imagined political community - and imagined as both inherently limited and sovereign. It is imagined because the members of even the smallest nation will never know most of their fellowmembers, meet them, or even hear of them, yet in the minds of each lives the image of their communion" (2006:6). Nation-states are formed through the imagination because people first imagine that groups who speak the same language and share the same religion and culture have shared a long existence together, originating and continuing from some point in the mythical past. That long existence coupled with a common language, religion, and culture form the fundamental arguments of the nation, which has to "be imagined, and, once imagined, modelled, adapted and transformed" (Anderson 2006:148). The process of transformation can be defined as assimilation, which is one of the policies nation-states use to homogenize their populations. Homogenization becomes easier if people believe (or are made to believe) that their nation always existed. Sand states that, "after the collapse of the Ottoman Empire, the inhabitants of the new Turkey found that they were white Aryans, the descendants of the Sumerians and the Hittites" (2009:16). Many nations in the modern world think alike with regard to their origins and national continuity.

Pains of Autumn is situated in a nationalist context in which the September Events deeply affect the lives of the non-Muslim minorities of Turkey. The protagonists of the novel are Ester and Behçet, whose lives clash just before the September Events. Ester, the female protagonist, is a Turkish Jew earning her living in Beyoğlu through prostitution arranged by her grandmother, who is also named Ester. Behçet, the male protagonist, is a young and handsome Muslim student in the Faculty of Medicine at a local university. A graduate of Galatasaray High School, he is fluent in French and has good taste in art and music. Raised by a conservative family from Konya and educated by a Sheik in Dargah, he has been visiting Galata and Bahariye Mevlevihanesi since his childhood (Karakoyunlu 2009:13). Those were the education and worship centers of the Mevlevi order (a religious community) in İstanbul. His father, Hacı Kamil Efendi, is a pious Muslim and a member of the DP. Although Ester and Behçet have different lifestyles and backgrounds, they fall in love. Knowing that she is a prostitute, Behçet avoids having sexual intercourse with her. He prefers voyeurism, looking at her body (2009:30-31-72). Nonetheless, Behçet is depicted as an honorable and respectable man, a character that embodies the high moral values of Turkish society, such as virtue, honesty, loyalty, and honor; whereas Ester is depicted as immoral and corrupt. Grandmother Ester and Ester's mother are also morally corrupt characters. Grandmother Ester was also a prostitute in her youth (2009:210), a profession she calls not fate but a choice (2009:129). Ester's mother was adulterous, and eloped with a lover when Ester was very young (2009:10). Karakoyunlu depicts three generations of that family as 
morally corrupt, suggesting that prostitution is somehow in their nature.

Another woman character is Madam Rhea, a Constantinopolitan Greek, who is in love with Behçet's father, Hacı Kamil Efendi. Rhea is the childless widow of Alex, a fisherman. Non-Muslim women here-and in many similar novels - are portrayed as great admirers of Muslim men and eager to have love affairs. Madam Rhea desires a sexual relationship with Hac1 Kamil Efendi, but he refuses her. Nevertheless, she does not give up and confesses her desire for him (Karakoyunlu 2009:29). This confession shows her corruption, as it is not decent for a woman to show her desire for sex in Turkish society. Sex is not discussed openly in traditional Turkish society because it is a taboo. On the other hand, Hacı Kamil Efendi, a Muslim Turk with high dignity, refuses Madam Rhea because he is virtuous and moral. The concept of morality is generally equivalent to sexuality in Turkey. Another woman who earns money from prostitution is Madam Atina, a Constantinopolitan Greek and owner of a brothel. Tanaş, the greengrocer, is depicted as a greedy man who overcharges Behçet (Karakoyunlu 2009:63-64). Moreover, Ester's father was addicted to gambling (Karakoyunlu 2009:76). These characters - together with the Armenian and Kurdish characters in the book-do not appear very often, but certainly show the ethnic diversity of Istanbul in the 1950s.

Since Ottoman times, Turkish authors and intellectuals have held different perspectives toward minorities. Hercules Millas analyzed almost four-hundred Turkish literary works and classified them according to their approach to the "Other," the Millet-i Rum who were the Orthodox Christians of Asia Minor. As Bernard Lewis explains, "The word used by the Turks, and more generally by Muslims in the Middle East, to designate the Greeks is Rum. But Rum doesn't mean Greeks; Rum means Romans, and the use of the name, first by the Greeks themselves and then by their new Muslim masters, echoes their last memory of political sovereignty and greatness" (1998:12). According to Millas, Turkish authors and novelists generally followed the most influential ideologies of their era (2000:1). The image of the "Other" is negative in Turkish literature because, as Millas states, "The images in literature carry a meaning beyond a personal conflict. Social values and beliefs form their realities within this social framework" (2000:8) According to Millas, writers like Cevat Şakir Kabaağaçlı, Kemal Tahir, Fikret Otyam, Hasan İzzettin Dinamo and Y1lmaz Karakoyunlu should also be termed "Anatolianist." Anatolianists believe that the Orthodox Christians (or Rum) were Turkified. They are like Turks and part of Turkish society because they have lost their national character. The West is "bad" and it refers as the "Other" in the mind of Anatolianist. Anatolia and the East are superior to the West (Millas 2000:125). As indicated above, Anatolianists praise Anatolia and its culture. Anatolia is at the center of their writings. However, as Millas stresses, Anatolianists sometimes act like humanists, socialists, liberals or nationalists, as well (2000:125). Y1lmaz Karakoyunlu might be regarded as an Anatolianist owing to the positive image of minorities and positive relations between Turks and non-Muslims that he presents in his novels (Millas 2000:125). However, his depiction of non-Muslim women characters in Pains of the Autumn shows his nationalist point of view, as well.

As an Anatolianist, the author emphasizes the good relationships between Turks and minorities. The life-long friendship between Madam Rhea and Hac1 Kamil Efendi and their visit to Eyüp Sultan Mosque and Saint Antuan Church, respectively, (Karakoyunlu 2009:26) make the author Anatolianist. The characters of Pains of Autumn are respectful toward others' faiths. Here, the author, as an Anatolianist, emphasizes religious tolerance in Turkey (Millas 2000:147). Millas explains that Karakoyunlu 
works from a liberal worldview as he criticizes the policies of the Turkish Republic (2000:145). In his analysis of Pains of Autumn, Millas claims that Karakoyunlu ignores the ethnic dimension of the September events and prefers to reflect the issue from a class conflict (2000:148). This article also claims that Karakoyunlu ignores the ethnic conflict between non-Muslims and Turks during the riot. He conceals the reality of conflict through positive relations and love affairs between different ethnic groups. The September Events occur toward the end of the novel. Hac1 Kamil Efendi and Behçet try to help and rescue the minorities from the attacks of the plunderers. In the course of the rioting, Ester is beaten and raped by mobs until she is finally rescued by Behçet (Karakoyunlu 2009:207-208). Madam Rhea is attacked, as well, and she is rescued by Hac1 Kamil Efendi. This is a typical move on the part of Anatolianist authors: Turks save the lives of non-Muslims (Millas 2000:148).

A close reading of the novel from a feminist perspective reveals Karakoyunlu's nationalist outlook, a writer who prefers to humiliate the "Other" through his definition and development of female characters. Although he does not openly "other" the minorities of Turkey, his female characters in Pains of Autumn provide clues to his nationalist ideology because they fall outside the realm of mainstream Turkish values, which were considerably more conservative in the 1950s. It is typical of nationalist authors to depict Turks as superior to others in terms of lifestyle and moral standing. Non-Muslims, on the other hand, tend to be portrayed as morally inferior or worse: as enemies of the Turks historically and ethnically (Millas 2000:61). Millas states that nationalist authors frame national conflicts through gender and sexuality. In their work, an Orthodox Christian woman is never depicted as a devoted mother or a faithful girl. Instead, they are portrayed as prostitutes or otherwise morally compromised individuals. Moreover, Orthodox men are portrayed as sexually incompetent or even impotent, and their wives often elope with Turkish men (2000:86). Turkish literature in general shares this nationalist perspective toward minorities (2000:51). As a Turkish citizen and politician, Karakoyunlu follows the same pattern and presents no new perspectives on society and politics in modern Turkey.

After the horrific events, Hac1 Kamil Efendi proposes to Rhea, and advises her to convert to Islam and take a Muslim name, Esra (Karakoyunlu 2009:218). He even wants to have a son from Rhea, but Rhea confesses that it was she who was infertile, not her husband Alex (Karakoyunlu 2009:219). This confession reveals, of course, that Madam Rhea lied to Hac1 Kamil Efendi previously. In traditional Turkish culture, a woman's infertility is generally regarded as a shame, and much more shameful given the fact that she is a non-Muslim. This attitude is troubling. Because she is infertile, Hac1 Kamil Efendi refuses to marry her. Millas claims that in the novels of nationalist authors, relations between Orthodox Christians and Muslims do not have happy endings unless the Christian woman converts to Islam (2000:87). Madam Rhea does not convert because she does not marry Hacı Kamil Efendi. Conversion takes place usually only if the non-Muslim woman marries the Muslim man. In addition, Ester never marries Behçet. After the riot, Ester emigrates to Israel without bidding farewell to Behçet. She marries a medical doctor and has two sons, one of whom she names after Behçet. Madam Rhea also leaves Turkey and moves to Greece. The novel does not have a happy ending - in terms of Turkish nationalist thinking and literature - because Madam Rhea and Ester do not convert to Islam and become Turks. The typical nationalist, of course, wishes they would (Millas 2000:87).

The humiliation of women goes as far back as Aristotle, who declared woman inferior: "as between male and female the former is by nature superior and ruler, the latter 
inferior and subject" (1992:68). Negative attitudes toward woman continue today in practically all facets of society. Feminist theory teaches us that the role of women in society is determined by men, and that gender roles are socially constructed. Women have become everything except the opportunity to be themselves. As Simone de Beauvoir writes, "One is not born, but rather becomes, a woman" (1989:273). She argues that woman is regarded as the second sex in her influential study on woman, The Second Sex. Woman is destined to live according to the social norms of her society as they are organized, ruled, and controlled by men. According to de Beauvoir, "women represent only the negative" (1989:15). This negative outlook appears in almost every discipline from literature to art. According to feminist literary theory, the image of woman in literature is negative (Irzık and Parla 2017). Furthermore, they are also confined to live in a language made by men (Irz1k and Parla 2017:8). Women are confined to live within narrow spaces created by men.

Negative discourse on, and views of, women affect all strata of society from politics to literature. Nationalist authors prefer to attack the state's enemies (in the case of Turkey, these have historically been Greece and Armenia) by focusing on issues of female sexuality. According to Deniz Kandiyoti, women's sexual behavior assumes an important role in the differentiation of the nation and the "other" (2013:163). "Women bear the burden of being 'mothers of the nation' (a duty that is ideologically defined to suit official policy), as well as being those tasked to reproduce the boundaries of ethnic and national groups, who transmit the culture, and who are the privileged signifiers of national difference" (Kandiyoti 1991:429). As Kandiyoti states, national difference is "dependent on a demonized 'other" (1991:433). According to Nira Yuval-Davis, "construction of nationhood usually involves specific notions of both 'manhood' and "womanhood"" (1997:1). She continues, "Most of the hegemonic theorizations about nations and nationalism (for example, Gellner, 1983; Hobsbawm, 1990; Kedourie, 1993; Smith, 1986; 1995), even including, sometimes, those written by women (for example; Greenfield, 1992), have ignored gender relations as irrelevant (1997: 1). She also insists that nations are reproduced by women biologically, culturally, and symbolically. Bureaucrats and intellectuals are not the ones that reproduce nations (1997: 1).

Since nations are reproduced by women, the infertility of Madam Rhea represents the demographic inferiority of the nation she belongs to. It can be argued that the author intentionally depicts Madam Rhea as infertile because he does not want her to reproduce an offspring of Orthodox Christians in Turkey. Her infertility also prevents Hac1 Kamil Efendi from marrying her. Ester, however, marries in Israel and has two sons. Her naming one of them Behçet indicates that her admiration of Behçet continues in spite of their separation. Grandmother Ester also was unable to forget one of her Turkish lovers from youth. It seems that admiration of Turkish men is a life-long feeling among non-Muslims in nationalist books like Pains of Autumn. We should also consider the fact that Ester gives her son a Muslim name while living in Israel under the cloud of religious conflict. It seems rather unrealistic. The author romanticizes their love and ignores the political realities of his time. Moreover, Madam Rhea moves to Greece and names her apartment "Ester." Millas states that Greeks do not name their apartments (1994:60). As an Anatolianist, the author follows the traditions of Turkish people who sometimes do so.

Women, who reproduce nations, are treated badly and often experience sexual abuse in the work of nationalist writers. As Joane Nagel states, "Enemy women are more uniformly characterized as sexually promiscuous and available: sluts, whores, or 
legitimate targets of rape" (1998:257). Women are regarded as symbols of their nations because "[I]t was female virtue that became emblematic of the nation state: Marianne, Britannia and the Statue of Liberty all testify to the mythical power of 'woman' in the nation state" (Reid and Ward 2015:2). Women represent national honor for the traditionalist. Nagel states that, "While traditionalist men may be defenders of the family and the nation, women are thought by traditionalists to embody family and national honor; women's shame is the family's shame, the nation's shame, the man's shame" (1998: 254). Therefore, women's sexual corruption is regarded as the entire nation's corruption. Cynthia Enloe claims that

Men in many communities appear to assign ideological weight to the outward attire and sexual purity of women in the community because they see women as (1) the community's — or the nation's - most valuable possessions, (2) the principal vehicles for transmitting the whole nation's values from one generation to the next, (3) bearers of the community's future generations - or, crudely, nationalist wombs, (4) the members of the community most vulnerable to defilement and exploitation by oppressive alien rulers, and (5) those most susceptible to assimilation and co-option by insidious outsiders. All five of these presumptions have made women's behavior important in the eyes of nationalist men (2014:108).

According to Enloe, woman is a kind of commodity, a possession of the nationalist men. Women are the wombs of the nation whose duty is to reproduce offspring and transmit national culture to the following generations. For nationalist men, the future of the nation depends on exaggerated notions of women's loyalty, obedience, and morally symbolic fiber. These notions are oppressive, however-notions that women must behave "properly" because their actions are judged by men who seek to shape society according to nationalist ideology. Women's dignity is discussed and politicized, but the dignity of men is ignored.

\section{CONCLUSION}

This article analyzes Y1lmaz Karakoyunlu's nationalist perspective toward Turkey's non-Muslim minorities in Pains of Autumn. The September Events of 1955 were a turning point in the lives of Turkey's non-Muslim minorities, those citizens considered "imperfect" owing to their ethnic and religious affiliations. The Turkification process began with the Lausanne Convention and continued with The "Citizen Speak Turkish" Campaign. The Wealth Tax and the September Events accelerated the migration of nonMuslims abroad. The Cyprus issue was the main cause of the September Events between Greece and Turkey. Fuelled with Turkish nationalism, property belonging to non-Muslims was destroyed after the announcement that the birthplace of Mustafa Kemal Atatürk in Thessalonica had been bombed by Greeks. The September Events have continued to be a controversial issue discussed and debated by scholars and authors. There are both nationalist and humanist debates on the history of modern Turkey, as both parties try to explain why and how those traumatic events happened.

This article claims that Karakoyunlu is one of those who explain the September Events from a nationalist point of view rather than a humanist point of view. Although Karakoyunlu criticizes the policy of the Turkish state, he is unable to overcome his nationalist sentiments with regard to the "Other." In the novel, non-Muslim female characters are portrayed as morally corrupt with their simpering admiration of Turkish men. He distances himself from ethnic conflicts and approaches the issue from the 
perspective of class struggle, yet fails to declare the guilty ones. He does not humiliate the minorities explicitly, but the images he portrays of non-Muslim women are less than flattering — and oftentimes degrading - throughout the novel.

An attack on women is an attack on a nation. The sexual abuse of a woman signifies the enmity and hatred of nations toward its national enemies. Logically, then, hatred directed at women is directed at all members of her nation. The hatred aroused in a community towards the "Other" is essentially abstract; it only becomes concrete when figured upon women's bodies. War on the battlefield may finish, but the battle over women's bodies continues as a means of attacking a nation's enemy.

\section{BIBLIOGRAPHY}

AKGÖNÜL, Samim, Türkiye Rumları: Ulus-Devlet Çağından Küreselleşme Çă̆ına Bir Azınlı̆̆ın Yok Oluş Süreci, İstanbul, İletişim 2007.

ANDERSON, Benedict, Imagined Communities: Reflections on the Origin and Spread of Nationalism, London, Verso 2006.

ARI, Kemal, Büyük Mübadele: Türkiye'ye Zorunlu Göç, 1923-1925, İstanbul, Tarih Vakfı Yurt Yayınları 2010.

ARISTOTLE, Politics, Trans. Thomas Alan Sinclair, England, Penguin 1992.

BALİ, Rıfat, 6-7 Eylül 1955 Olayları: Tanıklar-Hatıralar, İstanbul, Libra 2014.

BILLIG, Michael, Banal Nationalism, London, Sage 1995.

ÇAĞAPTAY, Soner, Islam, Secularism, and Nationalism in Modern Turkey: Who is a Turk? U.K, Routledge 2006.

DE BEAUVOIR, Simon, The Second Sex. Trans. H.M. Parshley, England, Lowe and Brydone 1989.

DE ZAYAS, Alfred, "The Istanbul Pogrom of 6-7 September 1955 in the Light of International Law", Genocide Studies and Prevention: An International Journal, vol.2, no.2, 2007, pp. 137-154.

DEMIR, Şerif, “Adnan Menderes ve 6/7 Eylül Olayları”, İstanbul Üniversitesi Yakın Dönem Türkiye Araştırmaları Dergisi, vol. 12, 2007, pp. 37-63.

DINK, Hrant, "Ruh Halimin Güvercin Tedirginliği”, Agos, 2007, http://www.hrantdink.org/? Detail=301\&HrantDink=11\&Lang

ENLOE, Cynthia, Bananas, Beaches and Bases: Making Feminist Sense of International Politics, U.S.A, University of California Press 2014.

GRELE, Ronald J., "Movement without aim: Methodological and theoretical problems in oral history", Oral History Reader, edited by Robert Perks and Alistair Thomson, pp. 38-52, London, Routledge 1998.

GÜNAY, Çimen, "Taking up the gauntlet: fictionists in the Turkish parliament," European Journal of Turkish Studies, Thematic Issue 3, §. 1-69, 2005, Being a MP in Contemporary Turkey, Web. 22 February 2017.

GÜVEN, Dilek, Cumhuriyet Dönemi Azınlık Politikaları ve Stratejileri Bağlamında 6-7 Eylül 1955 Olaylarl, İstanbul, İletişim 2014.

."Riots against the Non-Muslims of Turkey: 6/7 September 1955 in the Context of Demographic Engineering,” European Journal of Turkish Studies, 2011. 
HERACLIDES, Alexis, The Greek-Turkish Conflict in the Aegean: Imagined Enemies, London, Palgrave Macmillan 2010.

HIRSCHON, Renèe, Heirs of the Greek Catastrophe, Oxford, Berghahn

Books 1998.

IRZIK, Sibel and Jale PARLA, comp., Kadinlar Dile Düşünce: Edebiyat ve Toplumsal Cinsiyet, İstanbul, İletişim 2017.

İÇDUYGU, Ahmet, Şule TOKTAŞ and B. Ali SONER, "The Politics of Population in a Nation-Building Process: Emigration of non-Muslims from Turkey", Ethnic and Racial Studies, vol. 31, no.2, 2008, pp. 358-389.

KANDİYOTI, Deniz, Cariyeler, Bacılar, Yurttaşlar: Kimlikler ve Toplumsal Dönüşüm, İstanbul, Metis 2013.

—. "Identity and its Discontents: Women and the Nation", Millennium: Journal of International Studies, vol. 20, no. 3, 1991, pp. 429-443.

KARAKOYUNLU, Yılmaz, Güz Sancısı, İstanbul, Doğan 2009.

KARPAT, Kemal, Osmanlı'dan Günümüze Etnik Yapılanma ve Göçler, İstanbul, Timaş 2010.

LEWIS, Bernard, The Multiple Identities of the Middle East, New York, Schocken Books 1998.

LOWENTHAL, David, The Past is a Foreign Country, U.K, Cambridge University Press 2015.

MICHAEL, Michailis, N., "History, Myth and Nationalism: The Retrospective Force of National Roles within a Myth-Constructed Past", Nationalism in the Troubled Triangle: Cyprus, Greece and Turkey, edited by Ayhan Aktar, Niyazi Kızılyürek \& Umut Özkırımlı, pp. 149-159, U.K, Palgrave Macmillan 2010.

MILlAS, Herkül, Türk Romanı ve "Öteki": Ulusal Kimlikte Yunan İmajı, İstanbul, Sabancı Üniversitesi Yayınları 2010.

. "Tarihle İlgili Bir Romanın Eleştirisi: Güz Sancısı", Toplumsal Tarih, 1994, pp. 59-60.

NAGEL, Joane, "Masculinity and Nationalism: Gender and Sexuality in the Making of Nations", Ethnic and Racial Studies, vol. 21, no. 2, 1998, pp. 242-269.

REID, Fiona \& Stephanie WARD, "Women, State and Nation: Creating Gendered Identities", Women's History Review, vol. 24, no.1, 2015, pp. 1-6.

SAND, Shlomo, The Invention of the Jewish People, London, Verso 2009.

THOMPSON, Paul, The Voice of the Past, U.K, Oxford University Press 2000.

VRYONIS, Speros, The Mechanism of Catastrophe: The Turkish Pogrom Of September 6-7, 1955, and The Destruction of the Greek Community of Istanbul, U.S.A, Greekworks.Com 2005.

YUVAL-DAVIS, Nira, Gender and Nation, Thousand Oaks: Sage 1997. 